\title{
Modeling Investigation to Support Integrated Water Management in Southern Ontario: Considering Climate Change and Urbanization
}

\author{
Mark de Lange and Ed McBean \\ University of Guelph, Guelph, Ontario
}

\begin{abstract}
Confronted with an array of water management related challenges, Canadian municipalities are beginning to appreciate the myriad benefits of integrating initiatives for municipal water management. This integrated approach to water governance is intended to maintain the integrity of water sources, reduce damages from flooding, and promote environmental health through collaborative water management initiatives at a catchment level. In the interest of assessing the impact of urban development on flood risk, a model was developed to simulate the hydrological impacts of upstream development on downstream communities for a small catchment in Southern Ontario. Runoff hydrographs were determined through USEPA SWMM simulations for (1) pre-development, (2) post-development (status quo), and (3) green infrastructure development. The runoffs from these three scenarios are described using climate adjusted design storms of duration $1 \mathrm{~h}, 6 \mathrm{~h}$ and $24 \mathrm{~h}$ at return frequencies of $2 \mathrm{y}, 10 \mathrm{y}$ and $100 \mathrm{y}$. The effects of these events on flood risk to downstream communities were evaluated using a HEC-RAS simulation of a $2 \mathrm{~km}$ river reach.
\end{abstract}

\section{Introduction}

Canadian municipalities are being confronted by a broad range of water management challenges brought forth by population growth, urban sprawl, aging infrastructure, and climate change. As a result abilities to effectively manage runoff from wet weather events are limited. In an effort to combat these threats, municipalities are beginning to recognize the benefits of collaborative efforts towards the management of water resources. Through the adoption of an integrated approach to water management, municipalities are capable of minimizing the demands and impacts of their communities on water resources in order to protect people, property and the environment.

The Global Water Partnership (2010) defines integrated water management as the "process which promotes the coordinated development and management of water, land and related resources in order to maximize economic and social welfare in an equitable manner without compromising the sustainability of vital ecosystems." This cross-sector water management strategy can lead to increased efficiency in water usage while protecting, but not limiting, growth in the catchment.

Integrated approaches to water resources management, or the One Water approach, were developed to reduce the impacts of municipalities on the natural hydrologic cycle. Most significantly, when considering climate and urbanization, there can be substantial impacts on a catchment's water balance. Hassing et al.
(2009) highlighted the benefits of integrated water management, describing this strategy as beneficial in maximizing economic and social welfare without compromising the sustainability of ecosystems, through complementary development of resources.

Given the above merits to integrated water governance, many municipalities across Canada recognize the benefits of this approach, but struggle with how to adapt these strategies in their municipalities (OCSI 2014). In order to provide direction for developing integrated water management strategies, Canadian practitioners were asked in a recent survey to identify the greatest priorities to be considered when developing new risk management plans. From this survey of 84 municipal water workers, the top priorities were identified as climate change, aging infrastructure and urbanization (de Lange et al. 2016).

The objective of this research was to evaluate the effects of urban development on watershed hydrology, and the associated impacts on downstream communities, including downstream flooding and loss of groundwater recharge. As part of assessing the impacts of urban development, green infrastructure (GI), in the form of infiltration trenches, is investigated to evaluate its impact on the mitigation of the risks described above. A secondary goal of this research is to demonstrate the use of modeling tools that are readily available to municipalities and their consultants in such manner that they may carry out similar assessments specific to their catchments.

de Lange, Mark and Ed McBean. 2017. Modeling Investigation to Support Integrated Water Management in Southern Ontario: Considering Climate Change and Urbanization. Journal of Water Management Modeling 25:C425.

https://doi.org/10.14796/JWMM.C425 @ CHI 2017. www.chijournal.org ISSN 2292-6062. 


\section{Background on Applied Models}

The modeled area is a small catchment located in a Southern Ontario watershed. Within this catchment, the land surface slopes toward a central river system, which drains runoff from wet weather events occurring within the catchment. The outlet from the area of interest is a single river at the southernmost point of the catchment. Gaining insight to the variations in river flows at the catchment outlet is the primary objective for this investigation, in an effort to evaluate the potential effects of climate change and urban growth on the risk of flooding in downstream communities.

Figure 1 describes the basic logic employed in the model. The primary input to the model is precipitation in the form of idealized design storms or intensity-frequency-duration (IDF) curves. Climate change is addressed in the model by means of adjusted precipitation to account for projected changes in storm intensity. These storm adjustments were attained using readily available web based tools, as described below. Precipitation events are subsequently fed into a rainfall-runoff surface model for the three surface cover scenarios of interest. Finally, site runoff for all scenarios is fed into a generic river model to assess the impacts of precipitation events on downstream communities.

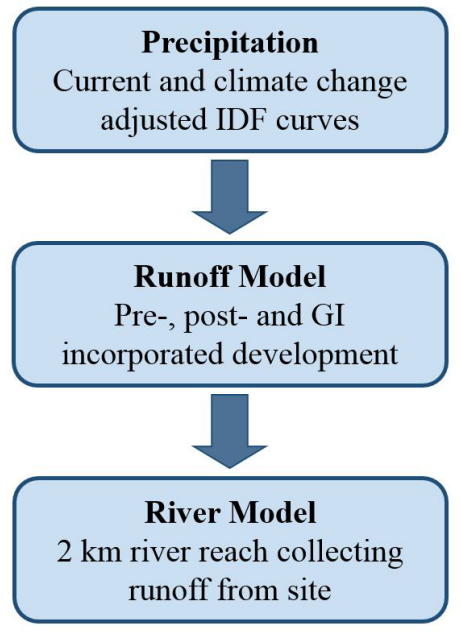

Figure 1 Flow diagram of hydrologic catchment model.

The following sections will detail the various model elements that are described in Figure 1.

\subsection{Runoff Model}

The runoff model was developed using the USEPA (United States Environmental Protection Agency) storm water management model, SWMM, for the three scenarios of interest. To use this program, the catchment area was divided into a series of subcatchments. SWMM treats each subcatchment as a nonlinear reservoir (see the conceptual model in Figure 2) assuming that discharge from the reservoir is not constant over time.

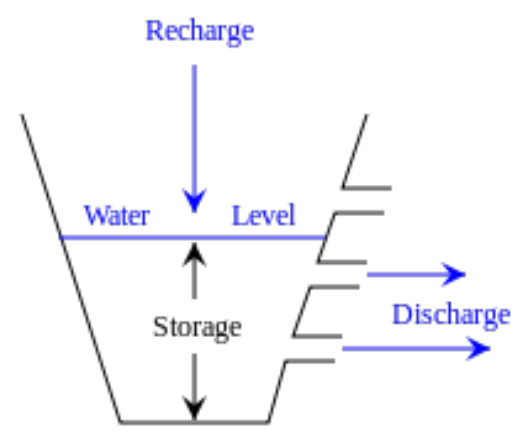

Figure 2 Cross section view of an idealized nonlinear reservoir model.

There are three possible sources of inflow to each subcatchment: precipitation, snowmelt, and overland flow from upstream subcatchments. Overland flow is modeled using a sheet runoff characterization, with pervious and impervious areas assigned a depression storage (the volume below the lowest outlet in Figure 2). Runoff occurs from a subcatchment when depression storage is exceeded by the inflows. Reservoir outflow is characterized by infiltration, surface runoff, and evaporation from surface storage.

\subsection{Climate Adjustments to IDF Curves}

IDF curves describe idealized precipitation events of known recurrence frequency (e.g. storms occurring every $2 \mathrm{y}, 10 \mathrm{y}$ and $100 \mathrm{y}$ ) and are used in the design and evaluation of municipal drainage networks. In this investigation, IDF curves were used to assess water balance impacts through precipitation occurring on upstream urban areas.

The mostly widely accepted method for modeling global climate, both for present and future atmospheric composition, is through the use of general circulation models (GCMs). GCMs are mathematical models that describe the physical processes of the Earth's atmosphere, oceans, cryosphere and land surface, with applications in climate study or weather forecasting, and are the best available tools for forecasting the impacts of climate change (IPCC 2013).

An essential input for GCMs when investigating the impacts of climate change on precipitation patterns is the composition of Earth's atmosphere for the period of interest. In this context, the IPCC (Intergovernmental Panel on Climate Change) has defined a series of representative concentration pathways (RCPs) to describe future atmospheric compositions based on a series of global development storylines. These storylines are the most widely accepted indicators of future GHG (greenhouse gas) composition, describing emissions through to the year 2100 as a function of global development based on demographic, socio-economic and technological development.

The global development scenarios described by the IPCC are categorized into families $\mathrm{A} 1, \mathrm{~A} 2, \mathrm{~B} 1$ and $\mathrm{B} 2$. In general, global development is focused on economic growth in the A scenarios, while $B$ scenarios describe global development with an emphasis 
on environmental health. For the scale of development, 1 scenarios focus on management of issues at a global scale while 2 scenarios emphasize problem solving at a local scale. Table 1 describes the details of each development scenario.

Table 1 Details of emission scenario families as described in the IPCC’s Special Report on Emission Scenarios (IPCC 2000).

\begin{tabular}{|c|c|c|c|c|}
\hline & Global population & Economy & Technology & Governance \\
\hline A1 & $\begin{array}{l}\text { Peak mid-century } \\
\text { followed by decline. }\end{array}$ & $\begin{array}{l}\text { Fastest growth of all } \\
\text { scenarios with em- } \\
\text { phasis on coordinated } \\
\text { development at a } \\
\text { global scale. }\end{array}$ & $\begin{array}{l}\text { Rapid introduction of } \\
\text { new or more efficient } \\
\text { technologies. }\end{array}$ & Regional approach. \\
\hline A2 & $\begin{array}{l}\text { Continuously } \\
\text { increasing. }\end{array}$ & $\begin{array}{l}\text { Emphasis on growth } \\
\text { of regional economies } \\
\text { with lowest per capita } \\
\text { global growth. }\end{array}$ & $\begin{array}{l}\text { Disjointed develop- } \\
\text { ment, leading to slow } \\
\text { implementation of } \\
\text { new technologies. }\end{array}$ & $\begin{array}{l}\text { Local scale, with pres- } \\
\text { ervation of regional } \\
\text { identities. }\end{array}$ \\
\hline B1 & $\begin{array}{l}\text { Peak mid-century } \\
\text { followed by decline. }\end{array}$ & $\begin{array}{l}\text { Steady growth, } \\
\text { smaller than that of } \\
\text { scenario A1. Transition } \\
\text { towards service and } \\
\text { information economy. }\end{array}$ & $\begin{array}{l}\text { Steady introduction } \\
\text { of clean and resource } \\
\text { efficient technologies. }\end{array}$ & $\begin{array}{l}\text { Global solutions to } \\
\text { economic, social and } \\
\text { environmental issues. }\end{array}$ \\
\hline B2 & $\begin{array}{l}\text { Continual population } \\
\text { growth below that of } \\
\text { A2 scenario. }\end{array}$ & Intermediate growth. & $\begin{array}{l}\text { More rapid develop- } \\
\text { ment than scenario } \\
\text { A2, less rapid and } \\
\text { more diverse than } \\
\text { scenarios } A 1 \text { and } B 1 \text {. }\end{array}$ & $\begin{array}{l}\text { Local and regional } \\
\text { approach. }\end{array}$ \\
\hline
\end{tabular}

Based on these global scenarios, future emissions of carbon dioxide, other greenhouse gases and sulfur combine to provide a wide spectrum of overlapping emission ranges which widens over time. These emission rates were extracted from recent literature and the IPCC Emission Scenario database (i.e. previous reports: IPCC 1990; IPCC 1992; IPCC 1994).

Figure 3 depicts the cumulative carbon dioxide emissions (in Gt/y) for the four families of emission scenarios described above, categorized as low, medium-low, medium-high, and high. Bars along the right hand side of this figure show the projected range for each emissions scenario at 2100 and the range for the IPCC (1992) report on emission scenarios.

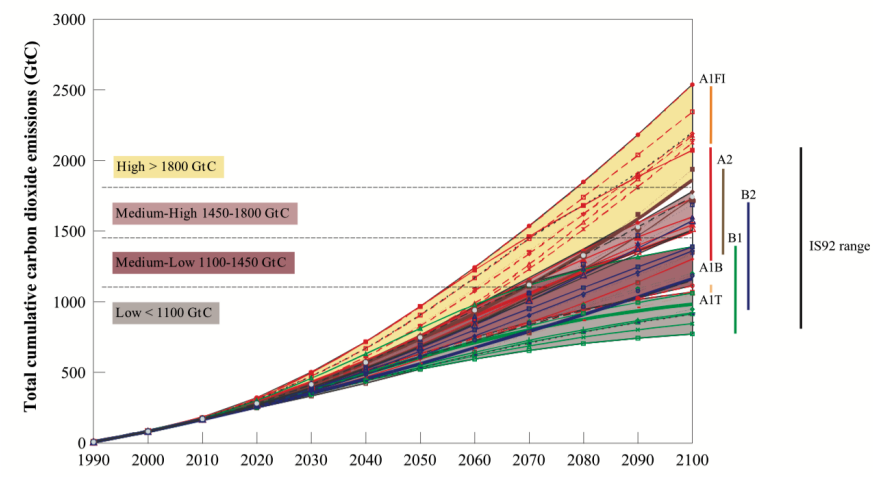

Figure 3 Cumulative carbon dioxide emissions from 1990 to 2100 for the four families of emission scenarios described in the IPCC's Special Report on Emission Scenarios (IPCC 2000).
The IPCC (2000) report recommends the use of a range of emission scenarios in modeling, as opposed to central values, to provide a range of climate projections as opposed to a single value with a high degree of uncertainty. However, given the large number of variables in this analysis (development type, storm return period, storm duration) a central value was selected for simplicity. This value provides an estimate for some degree of impact from climate change but further analysis will be required to characterize unique the impacts of the various emissions families described above.

Following the completion of GCM modeling for future atmospheric conditions, the IDF curves for climate change were modified to current and projected climate conditions as described in Figure 4. This methodology assumes a constant relationship between modeled climate variables and short duration precipitation events. Using GCMs, current climate conditions are modeled using the existing atmospheric composition (labeled GCM Baseline in Figure 4). From these results, a relation is established between current GCM outputs and the historical precipitation record which is subsequently extrapolated to estimate short duration storm events for future GCM outputs (GCM Projection in Figure 4).

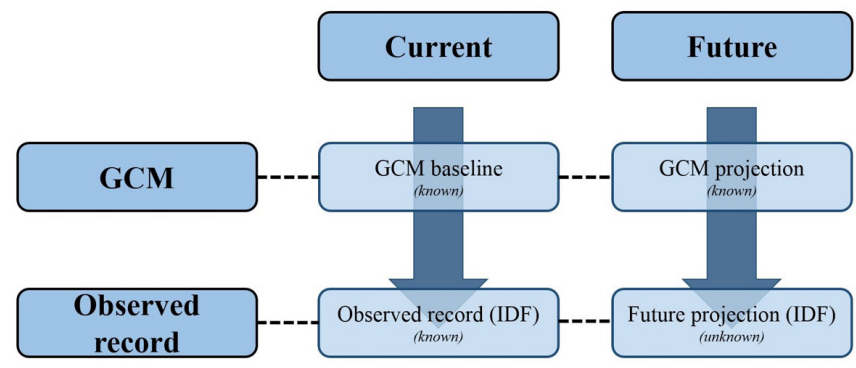

Figure 4 Methodology for development of IDF curves for future climate, based on historical rainfall records and GCM simulations of both current and future climates (adapted from Wang 2015).

\section{Modeling Methodology}

\subsection{Runoff Model}

A site specific runoff model was developed for each of the three surface cover scenarios: pre-development; post-development (status quo); and green infrastructure (Gl) amended development. To generate the pre-development surface model local topographic and soil maps were used. Topographic maps were created from a digital elevation model (DEM) of the Grand River (Ontario) watershed at a vertical resolution of $5 \mathrm{~m}$ (GRCA 2016). From this terrain data, land slopes were extracted for the pre-development site. For both post-development scenarios, a slope of $2 \%$ was assigned to each lot to ensure adequate drainage, as recommended in the Ontario design guidelines (MOE 2003).

Table 2 summarizes the contrast in surface characteristics used in modeling pre- and post-development prior to the 
incorporation of $\mathrm{Gl}$. The pre-development land slope follows that of the existing conditions and therefore varies from catchment to catchment.

Table 2 Summary of pre- and post-development model parameters for sample subcatchments in the EPA SWMM model.

\begin{tabular}{lcc}
\hline \multicolumn{1}{c}{ Parameter } & Pre-development & Post-development \\
\hline Average \% impervious & $5 \%$ & $56 \%$ \\
Slope & variable & $2 \%$ \\
Overflow length & $150 \mathrm{~m}$ & $20 \mathrm{~m}$ \\
\hline
\end{tabular}

A pre-development maximum overland flow length of $150 \mathrm{~m}$ was selected. This value represents the distance of overland flow for pre-development conditions that will occur before the assumption of sheet flow is no longer valid (i.e. the formation of rivulets). For post-development conditions, an overland flow length of $20 \mathrm{~m}$ is assumed, representing the average flow length from the back property line to the road centreline.

Table 3 summarizes the contrasts of pervious to impervious surface covers applied in the runoff model. As described above in Table 2, pervious cover is substantially increased through urbanization, mainly attributed to roads, driveways, rooftops and parking lots. A small portion of impenetrable surface area is also assumed in pre-development conditions to account for the interception of precipitation by vegetation and rocks.

Table 3 List of surface parameters for a sample subcatchment within the developed area.

\begin{tabular}{lcc}
\hline \multicolumn{1}{c}{ Parameter } & Pervious & Impervious \\
\hline Manning's $n$ & 0.015 & 0.24 \\
Storage depth & $7.62 \mathrm{~mm}$ & $1.52 \mathrm{~mm}$ \\
Directly connected impervious area & $25 \%$ & - \\
Infiltration model & Horton & - \\
Max infiltration rate & $114.3 \mathrm{~mm} / \mathrm{h}$ & - \\
Min. infiltration rate & $5.08 \mathrm{~mm} / \mathrm{h}$ & - \\
Decay constant & $4 \mathrm{~h}^{-1}$ & - \\
Drying time & $7 \mathrm{~d}$ & - \\
\hline
\end{tabular}

Storage depth, or surface ponding, represents the volume of water that can be stored on the surface prior to the occurrence of runoff. As seen in Table 3 this value is significantly larger for pre-development conditions due to the smooth surface of the developed sites.

In the post-development scenario, including $\mathrm{Gl}$, infiltration trenches were added to the developed site to intercept a portion of runoff at the lot level prior to conveyance to the end-of-pipe infrastructure. These trenches are located along the back property line of each lot, collecting runoff from the two adjacent properties. Table 4 summarizes the model parameters for the infiltration trenches used across the study area. These infiltration trenches were designed in accordance with USEPA (USEPA 1999) and Ontario MOE guidelines (MOE 2003).
Table 4 List of parameters used in the modeling of infiltration trenches.

\begin{tabular}{lc}
\hline \multicolumn{1}{c}{ Parameter } & Value \\
\hline Storage depth & $400 \mathrm{~mm}$ \\
Width & $1 \mathrm{~m}$ \\
Area & $40 \mathrm{~m}^{2}$ \\
Trench bottom percent impervious & $100 \%$ \\
\hline \multicolumn{2}{c}{ Infiltration model: Horton } \\
\hline Max. infiltration rate & $5 \mathrm{~mm} / \mathrm{h}$ \\
Min. infiltration rate & $5 \mathrm{~mm} / \mathrm{h}$ \\
\hline
\end{tabular}

A constant exfiltration rate, recharging groundwater, was assumed at fully saturated conditions from the trench bottom. This conservative approximation assumes that the trench bottom never fully dries between precipitation events, reducing the capacity for infiltration.

The piped drainage network for both post-development scenarios was oversized such that all runoff from all storm events is conveyed to the end-of-pipe peak flow management facilities without localized flooding.

An end-of-pipe stormwater management pond (SWMP) was designed to match peak flow discharges for pre-development conditions for three critical events: the $2 \mathrm{y}, 10 \mathrm{y}$ and $100 \mathrm{y}$ recurring storms. Two orifices were designed to match predevelopment peak flows for the $2 \mathrm{y}$ and $10 \mathrm{y}$ storm events while a weir was used to release runoff from the $100 \mathrm{y}$ or larger event. This means that runoff volumes from storms that exceed a recurrence frequency of $100 \mathrm{y}$ cannot be effectively mitigated by the SWMP.

\subsection{Climate Change}

In this analysis, when evaluating the impact of climate change on IDF curves, and the ensuing impacts to drainage infrastructure, the web based Computerized Tool for the Development of IntensityDuration-Frequency Curves under Climate Change (IDF_CC tool) was used (Simonovic et al. 2015). This tool contains a database of 22 GCMs referenced in the IPCC's Fifth Assessment Report (AR5), developed by various climate research centres around the world. The most appropriate model for a unique location is automatically selected using a quintile regression skill score (QRSS) based method to rank the models by applicability (Srivastav et al. 2015).

For generating baseline IDF curves, historical precipitation records are automatically sourced from Environment Canada weather stations or manually input by the user. To provide accurate estimates of local patterns, the IDF_CC tool requires a complete data set of a minimum $10 \mathrm{y}$ duration. Based on this data set, IDF curves are developed by fitting the storm record to a Gumbel extreme value distribution (Peck and Simonovic 2009; Vasiljevic 2007; MTO 1997).

Three RCPs from the IPCC's special report Emission Scenarios (IPCC 2000) were used to characterize future concentrations of GHGs in the atmosphere. RCPs 2.6, 4.5 and 8.5 were selected as this range includes moderate, median and extreme emission rates of GHGs, chemically active gases, aerosols, and land use changes. This large range is suitable in order to account for the substantial 
uncertainty in climate modeling based on long range atmospheric conditions (Moss et al. 2007). Table 5 summarizes the various peaking factors used to adjust current IDF curves, developed from historical precipitation records, to account for climate change.

Table 5 Summary of peaking factors to adjust design storms to account for climate change (Simonovic et al 2015).

\begin{tabular}{lcccc}
\hline & $2 \mathrm{y}$ & $5 \mathrm{y}$ & $25 \mathrm{y}$ & $100 \mathrm{y}$ \\
\hline $2 \mathrm{~h}$ & 1.65 & 1.68 & 1.70 & 1.68 \\
$6 \mathrm{~h}$ & 1.33 & 1.28 & 0.71 & 0.69 \\
$24 \mathrm{~h}$ & 1.20 & 1.11 & 1.08 & 1.04 \\
\hline
\end{tabular}

IDF curves currently used for the design of urban drainage networks in Ontario were used as a baseline (prior to climate change adjustment) in this analysis. These trends were obtained from the Ministry of Transportation Ontario (MTO) IDF Curve Lookup website (MTO 2013).

\subsection{Receiving River Model}

Outflow from the runoff model is subsequently input to a HEC-RAS receiving river model. This model was developed using the HEC-GeoRAS tool to accurately characterize local terrain from DEM files (U.S. Army Corps of Engineers 2015). The use of this tool allowed for detailed data from the contour maps used in site modeling to be imported directly to HEC-RAS for a series of cross sections along the river reach of interest. Figure 5 is a screen shot of the input to the HEC-GeoRAS tool. In this Figure, the river boundary is shown in red, the river centreline in blue, and the river cross sections used in HEC-RAS model correspond to the green lines perpendicular to river flow.

Initial flow conditions for the river model were determined by adding a steady base flow such that river boundaries were not exceeded at any cross section locations.

\section{Results and Discussion}

\subsection{Lot Level Impacts of Development}

Local level implications of development were first examined to indicate the effectiveness of $\mathrm{Gl}$ in development at a lot level, for varying storm intensities. The three critical design storms of interest were modeled as single events. A water balance for each storm event for the three development scenarios is shown in Figure 6. The storms presented in this section have not been adjusted for climate change and are solely intended to evaluate how the site responds to different precipitation volumes. Storm events of $2 \mathrm{~h}$ were used as these higher intensity events place rapid stress on stormwater management systems.

Figure 6 summarizes water balance coefficients for the three surface cover scenarios for the $2 \mathrm{y}, 10 \mathrm{y}$ and $100 \mathrm{y}$ recurring storm events.

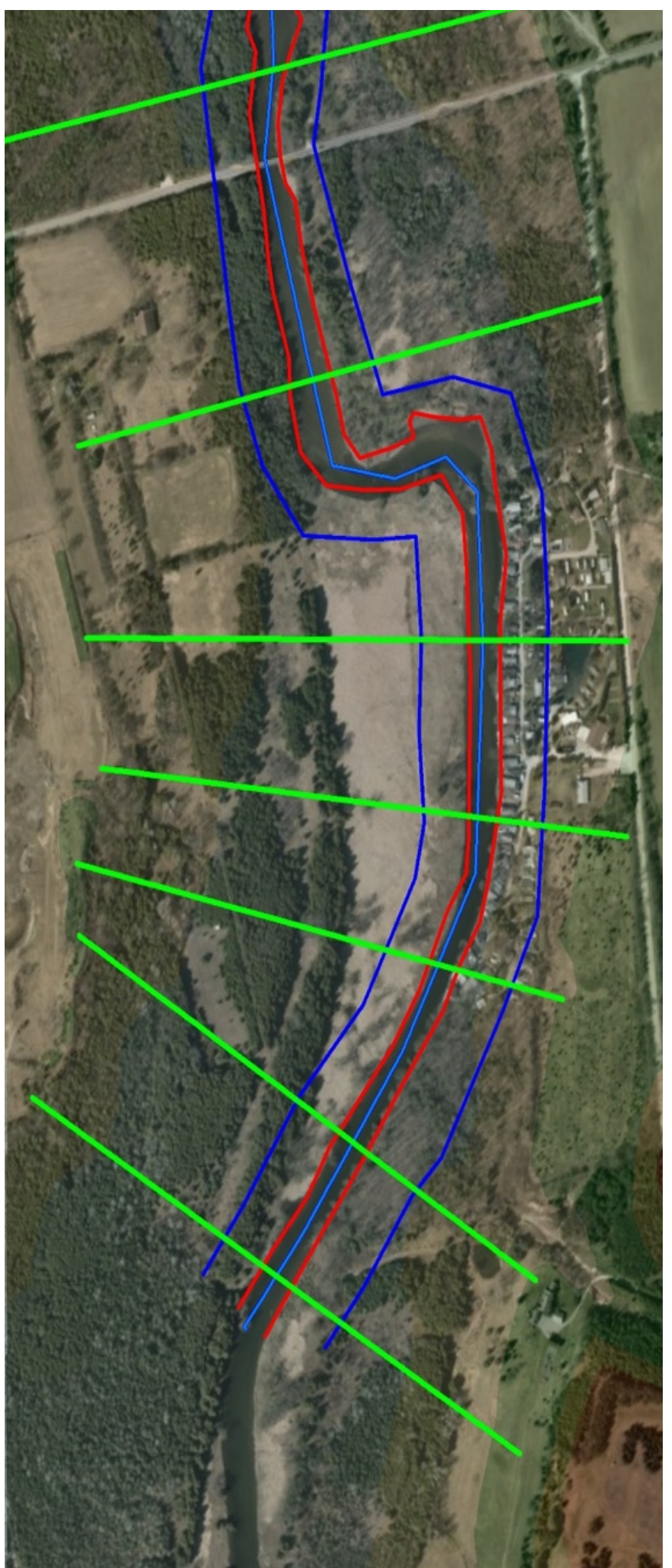

Figure 5 HEC-GroRAS model inputs (green: river cross sections; red: river boundaries; light blue: river centreline). 


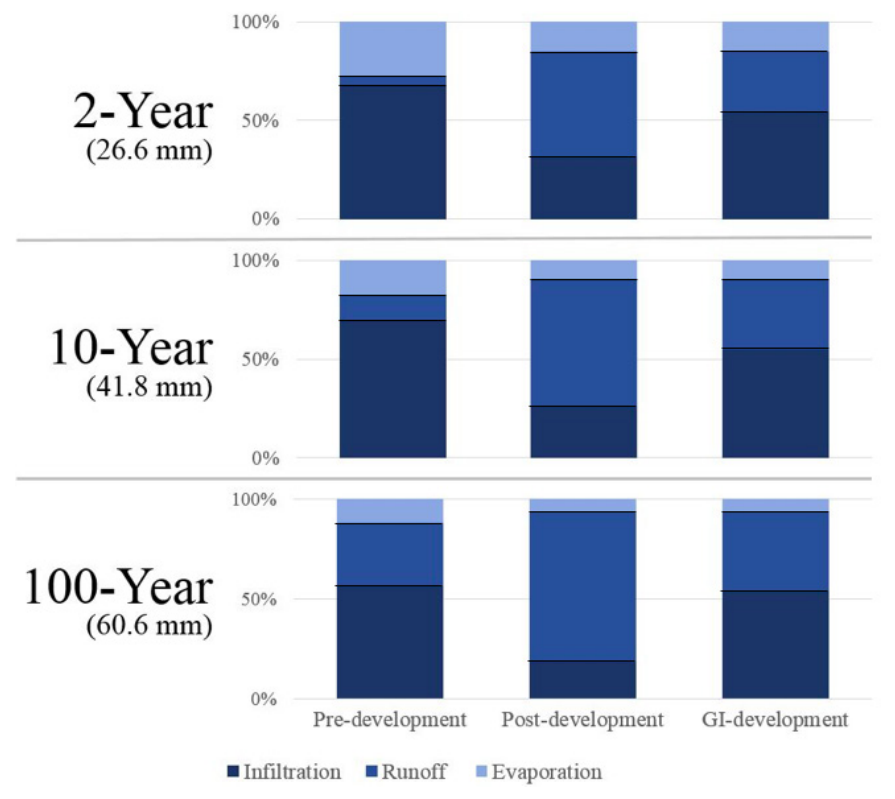

Figure 6 Water balance of the $2 \mathrm{y}, 10 \mathrm{y}$ and $100 \mathrm{y}$ recurring

$2 \mathrm{~h}$ storm events for pre-development, post-

development and GI-development sites.

In Figure 6, the total volume of precipitation corresponding to each storm event is indicated below each storm designation. Each bar represents a breakdown of all rainfall landing in the catchment (summing to 100\%). There are three possible destinations for precipitation within the catchment: infiltration, runoff and evaporation (distinguished in each case by the various shades of blue in Figure 6).

For pre-development conditions, the considerable majority of precipitation is infiltrated, with $>50 \%$ in all cases. The highest infiltration coefficients are seen for the low intensity storm events, with decreasing rates as the volume of precipitation increases. Evaporation for each event is determined through the volume of surface ponding for each surface cover scenario. This assumes that all water ponded on the surface either evaporates or is utilized by shallow-rooted vegetation (ET).

For post-development conditions (status quo) the infiltration and evaporation coefficients decrease substantially for all precipitation events, leading to increased runoff. ET is decreased due to significant transformation from pervious to impervious surface cover as roads, rooftops and driveways. Likewise, there is limited infiltration capacity due to the increase in impervious cover. Similar to pre-development conditions, the proportion of runoff increases with precipitation volume.

Finally, for the developed site with the incorporation of $\mathrm{Gl}$, the total volume of runoff is substantially decreased, resulting from the onsite storage provided by the infiltration trenches. For high intensity storm events the volume of infiltration trenches is exceeded by runoff, leading to overflows to the municipal drainage system. This onsite storage allows for infiltration to occur at a rate approaching that of pre-development conditions. Due to similar surface cover to the post-development (status quo), there continues to be a substantial decrease in ET from pre-development conditions.

Continuing to address the lot level water balance resulting from critical storm events, Figure 7 depicts surface runoff per hectare for the $2 \mathrm{~h}$ idealized storms of interest, falling on the three surface cover scenarios.

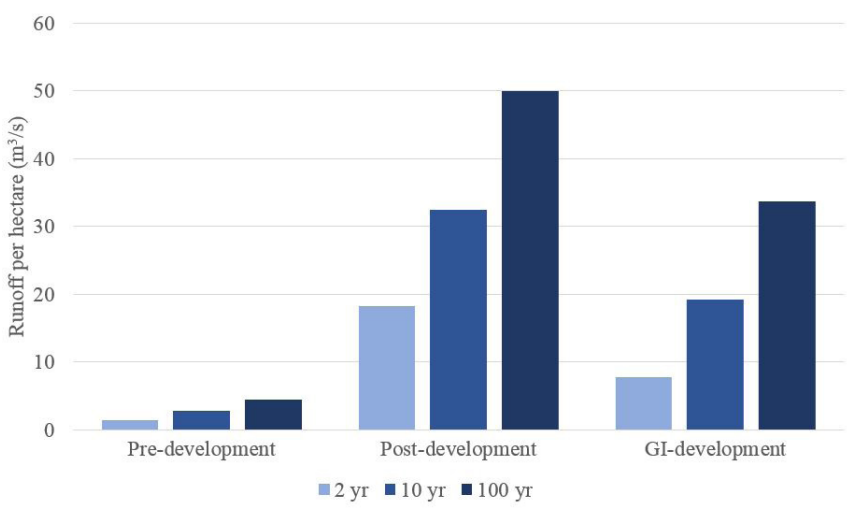

Figure 7 Runoff per hectare of site for three surface cover scenarios: pre-development; post-development; and post-development incorporating GI.

As is shown in Figure 7, the inclusion of Gl on the site substantially reduces outflow for the storm events of interest. For the 2 y design event, runoff is reduced by $11 \mathrm{~m}^{3} / \mathrm{s}(\sim 50 \%)$, $13 \mathrm{~m}^{3} / \mathrm{s}$ for the $10 \mathrm{y}(\sim 33 \%)$, and $16 \mathrm{~m}^{3} / \mathrm{s}$ for the $100 \mathrm{y}(\sim 25 \%)$. $\mathrm{Gl}$ becomes less effective at runoff reduction as precipitation volumes increase. The reduction in runoff volume is effective in working towards replicating pre-development water balances, although peak flows must also be investigated to address flood risk within the catchment. The following sections will address peak flow management from the outlet of the entire developed area, in order to address the flood risk in the receiving end of the catchment.

\subsection{Impacts of Development Following End-of- Pipe Stormwater Management}

To expand on the lot level implications of development, outflows from the entire site were also investigated. For the scenarios presented in this section, site runoff is conveyed to an end-of-pipe SWMP to control peak flows. The SWMP was designed to match pre-development peak flows for the $2 \mathrm{y}, 10 \mathrm{y}$ and $100 \mathrm{y}$ recurring storms based on historical precipitation records. For the upper limit of these design storms (100 y event) the performance of the stormwater management pond was evaluated using storms adjusted for climate change.

Figure 8 shows two outflow hydrographs from the site's SWMP to the downstream area for extreme storm events (100 y recurring) at durations of $2 \mathrm{~h}$ and $24 \mathrm{~h}$, both for an observation period of $30 \mathrm{~h}$. The ponds were designed to control peak flows for the developed area for the maximum flow corresponding to the 100 y storm event. Given the large capacity of the SWMPs, climate 
adjusted, higher intensity storms of lower occurrence (i.e. the climate adjusted $10 \mathrm{y}$ recurrence storm) were not investigated here as the SWMP would be capable of matching pre-existing peak flows for these less intense events.

2 Hour

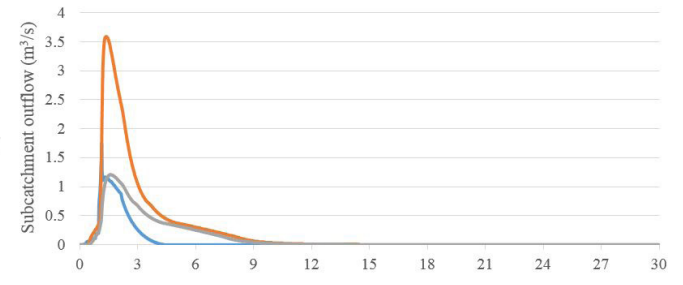

24 Hour

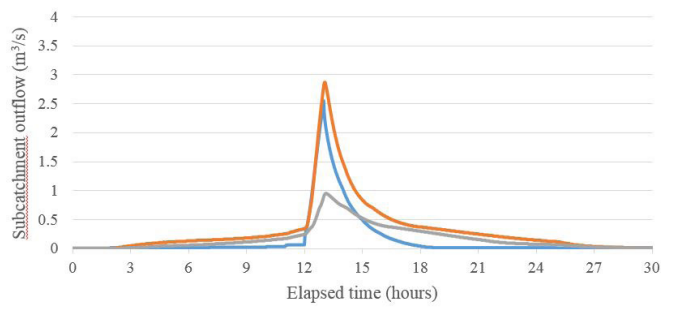

— GI-development (CC adjusted)

—Pre-development

- Post-development (CC adjusted)

Figure 8 Outflow hydrographs from the stormwater management pond treating runoff from the developed site (flows are for the $100 \mathrm{y}$ recurring climate change adjusted design storms of duration $2 \mathrm{~h}$ (upper) and $24 \mathrm{~h}$ (lower), both for three surface cover scenarios: predevelopment; post-development; and post-development with GI.

Peak flows are the highest outflow from the pond and correspond to the maximum value on each hydrograph. For the $2 \mathrm{~h}$ storm event (Figure 8, upper) for the post-development scenario, the capacity of the stormwater management pond is greatly exceeded by the climate adjusted storm indicated by a peak flow, $3.59 \mathrm{~m}^{3} / \mathrm{s}$, that is significantly higher than the pre-development conditions flow, $1.74 \mathrm{~m}^{3} / \mathrm{s}$. The addition of infiltration trenches at the lot level significantly reduced peak flows to $1.21 \mathrm{~m}^{3} / \mathrm{s}$.

For the storm of $24 \mathrm{~h}$ duration (Figure 8, lower), pre-development peak flows are essentially achieved for the developed site without the use of GI. SWMP outflows for the pre- and post-developed sites are $2.54 \mathrm{~m}^{3} / \mathrm{s}$ and $2.87 \mathrm{~m}^{3} / \mathrm{s}$ respectively. This can be attributed to two contributing factors: (1) the climate models project higher relative increases in precipitation for short duration storm events than for longer events; and (2) the volume of precipitation is distributed over a longer period of time. In addition to the climate adjustments, for the $24 \mathrm{~h}$ event, a gradual accumulation of precipitation in the pond will occur, allowing for controlled release over the duration of the storm. This is different from the large volume reaching the pond in a short duration storm that is seen in the $2 \mathrm{~h}$ event.

The introduction of Gl to the developed site further reduces the volume of runoff, resulting in a SWMP outflow lower than pre-development conditions. The post-developed site with GI has a peak outflow of $0.95 \mathrm{~m}^{3} / \mathrm{s}$.
These results indicate that the introduction of $\mathrm{Gl}$ at a lot level in developments can substantially reduce the runoff peak flows, most effectively for longer duration, lower intensity events. For these longer events, the SWMP is far from being filled to capacity, indicating the potential for reducing the volume needed for these facilitates. These results also demonstrate that infiltration trenches are a viable retrofit in development to complement SWMPs in runoff management from future storms.

\subsection{Implications at the Watershed Level}

To complete this investigation, SWMP outflows from the developed site were combined with the existing river flow to assess the risk of downstream flooding. The SWMP outflow hydrographs (Figure 8 above) were input to the HEC-RAS model of the receiving river for the $2 \mathrm{~km}$ river reach of interest. The $2 \mathrm{~h}$ storm events were selected for modeling because these short duration, high intensity events result in the highest flood risk as the peak flow management capacity of the SWMP is exceeded. Climate change was also considered by means of climate adjusted storms for the future surface cover scenarios: post-development and post-development with $\mathrm{Gl}$.

Figure 9 depicts the 100 y floodplain for a climate change adjusted storm intensity for the post-development site both with and without the incorporation of Gl. The dry weather river boundaries can be seen below the two floodplain layers.

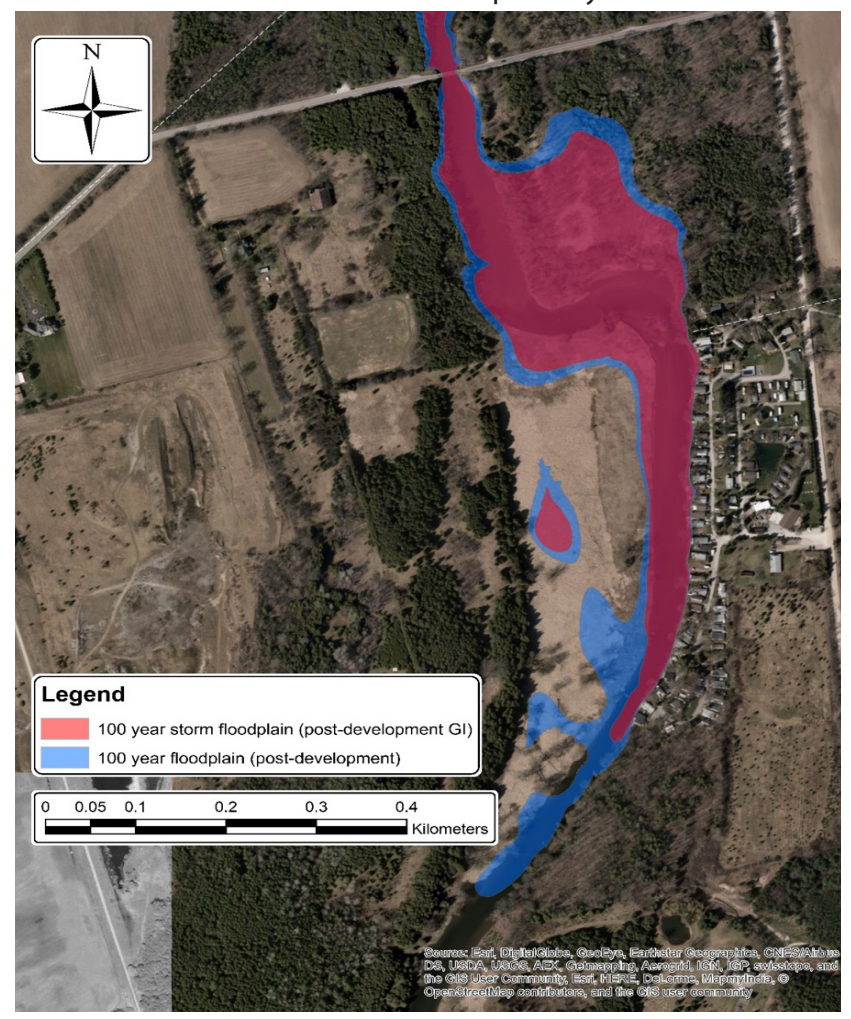

Figure 9 Flood map for the $2 \mathrm{~km}$ river reach, resulting from the $100 \mathrm{y}$ climate adjusted storm event occurring on the post-developed site (blue) and post-development with GI (red). 
As is shown in Figure 9, the introduction of $\mathrm{Gl}$ to reduce runoff at a lot level has a noticeable impact on stormflows at a catchment level. In this figure, the $100 \mathrm{y}$ recurring climate change adjusted storm was used based on emissions projected emissions to the year 2100. Through the inclusion of Gl, the resulting floodplain from this storm event was reduced by $29 \%$ for the modeled downstream area. This is a substantial impact and demonstrates how the inclusion of $\mathrm{Gl}$ can offset demands on traditional stormwater management systems to provide the flood protection necessary in a changing climate.

\section{Conclusion}

Through the above modeling exercise, it was determined that the incorporation of $\mathrm{Gl}$ in developments, in the form of local infiltration features, has a substantial effect on both promoting the natural water balance and reducing the risk of flooding in downstream portions of the catchment. These benefits are seen at a lot level as improved recharge of groundwater, resulting from the introduction of simple infiltration trenches along the back property lines in residential areas. At the catchment scale, the benefits of these features are seen in flood control. The introduction of these features offers both stormwater volume reduction and peak flow attenuation, reducing treatment demands on traditional end-of-pipe stormwater infrastructure. Furthermore, infiltration features at the lot level decreased the volume of runoff that needed to be treated by end-of-pipe faculties for the climate adjusted storms. This decrease in runoff volume reduces the risk that SWMP's capacities will be exceeded under the anticipated effects of climate change.

Although this investigation has concluded that onsite infiltration features are effective at promoting groundwater recharge for high intensity storm events, the true benefit to groundwater recharge would be more clearly understood through considering the more frequent smaller precipitation events that occur over the duration of a year. Given the purpose of this investigation was to assess the benefits of integrated water management in reducing flood risks, continuous hydrologic modeling is recommended to more clearly understand the advantages of these features to groundwater preservation. Further work is recommended to analyse the water balance benefits that could be provided by other types of green infrastructure on the proposed development.

\section{References}

de Lange, M., R. Harvey, Y. Wang and E. McBean. 2016. “The Water Utility Risk Integration Matrix: Demonstrating Potential for an Integrated Approach to Municipal Water Management." Journal of Water Management Modeling 24:C396. https://doi.org/10.14796/JWMM.C396.

Global Water Partnership. 2010. What is IWRM? Earth: Global Water Partnership. http://www.gwp.org/The-Challenge/What-is-IWRM/.
GRCA (Grand River Conservation Authority). 2016. Data Catalogue. Cambridge, Ontario: GRCA. https://maps.grandriver.ca/data-gis.html.

Hassing, J., N. Ipsen, T. J. Clausen, H. Larsen and P. Lindgaard-Jørgensen. 2009. Integrated Water Resources Managment in Action. Paris: Integrated Water Resources Management in Action (UNESCO). Dialogue Paper.

IPCC (Intergovernmental Panel on Climate Change). 1990. Climate Change: The IPCC Scientific Assessment. Cambridge: Cambridge University Press.

IPCC (Intergovernmental Panel on Climate Change). 1992. Climate Change 1992: The Supplementary Report to the IPCC Scientific Assessment. Cambridge: Cambridge University Press.

IPCC (Intergovernmental Panel on Climate Change). 1994. Radioactive Forcing of Climate Change and an Evaluation of the IPCCIS92 Emission Scenarios. Cambridge: Cambridge University Press.

IPCC (Intergovernmental Panel on Climate Change). 2000. Special Report on Emission Scenarios: Summary for Policymakers. IPCC.

https://www.ipcc.ch/pdf/special-reports/spm/sres-en.pdf.

IPCC (Intergovernmental Panel on Climate Change). 2013. What is a GCM? IPCC Data Distribution Centre. http://www.ipcc-data.org/guidelines/pages/gcm_guide. html.

MOE (Ontario Ministry of the Environment). 2003. Stormwater Management Planning and Design Manual. Toronto: Queens Printer for Ontario.

Moss, R., M. Babiker, S. Brinkman, E. Calvo, T. Carter, J. Edmonds, I. Elgizouli, S. Emori, L. Erda, K. Hibbard, R. Jones, M. Kainuma, J. Kelleher, J. F. Lamarque, M. Manning, B. Matthews, J. Meehl, L. Meyer, J. Mitchell, N. Nakicenovic, B. O'Neill, R. Pichs, K. Riahi, S. Rose, P. Runci, R. Stouffer, D. van Vuuren, J. Weyant, T. Wilbanks, J. P. van Ypersele and M. Zurek. 2007. Towards New Scenarios for Analysis of Emissions, Climate Change, Impacts, and Response Strategies. Geneva: Intergovernmental Panel on Climate Change. IPCC Expert Meeting Report.

MTO (Ontario Ministry of Transportation). 1997. Drainage Managment Manual. Ottawa: MTO.

MTO (Ontario Ministry of Transportation). 2013. IDF Curve Lookup. Toronto: MTO.

http://www.mto.gov.on.ca/IDF_Curves/terms.shtml.

OCSI (Ontario Coalition for Sustainable Infrastructure). 2014. When the Bough Breaks: Helping Municipalities Prioritize Infrastructure Investment to Build Resilient Wastewater and Stormwater Systems. Toronto: OCSI. http://www.on-csi.ca/cmsAdmin/uploads/WINA_Report_-When_the_Bough_Breaks_-_Nov_2014.pdf.

Peck, A. and S. P. Simonovic. 2009. Updated Rainfall Intensity Duration Frequency Curves for the City of London Under the Changing Climate. London, Ontario: The University of 
Western Ontario. Department of Civil and Environmental Engineering.

Simonovic, S. P., R. Srivastav, A. Schardong and D. Sandink. 2015. IDF CC Tool for Deriving Rainfall Intensity-Duration-Frequency Curves for Future Climate Scenarios. London, Ontario: The University of Western Ontario.

http://www.idf-cc-uwo.ca.

Srivastav, R. K., A. Schardong and S. P. Simonovic. 2015. Climate, Computerized Tool for the Development of Intensity-Duration-Frequency Curves under a Changing Climate. Technical Manual, Civil and Environmental Engineering. London, Ontario: The University of Western Ontario. http://www.idf-cc-uwo.ca/Manual/89.pdf.
U.S. Army Corp of Engineers. 2015. HEC-RAS River Analysis System Version 5.0. Davis, CA: U.S. Army Corp of Engineers. Computer Program.

USEPA (U.S. Environmental Protection Agency). 1999. Stormwater Managment Technology Fact Sheet: Infiltration Trench. Washington, DC: USEPA National Service Center for Environmental Publications.

Vasiljevic, B. 2007. Assessment of Changes in Precipitation Intensities in Ontario. Guelph: University of Guelph. MASc Thesis, School of Engineering.

Wang, Y. 2015. Climate Change and Municipal Stormwater Systems. White Paper. Guelph: University of Guelph. 